\title{
Note
}

\section{Copyright, Free Speech, and the Visual}

\section{Arts}

Artists and critics often incorporate copyrighted visual images into their work. While the use of these images may be central to the artist's creative expression, it may also result in liability for copyright infringement. Since these works of art integrally involve the communication of ideas, restrictions on the use of visual material thus inhibit freedom of speech. ${ }^{1}$

The doctrine of fair use-which accommodates for legitimate use of copyrighted material-fails to provide meaningful standards governing the use of visual, rather than written, material. A First Amendment defense to infringement actions involving the "appropriation" of copyrighted images would guarantee the free dissemination of ideas conveyed through visual media. Current interpretations of the First Amendment, however, reveal a bias against forms of speech in which the mode of expression is inseparable from the idea expressed. ${ }^{2}$

This Note will argue for an expansion of First Amendment interpretation to protect art works that appropriate visual images. It will examine the inadequacy of current copyright infringement provisions as applied to the visual arts and contrast how an expanded First Amendment defense would better protect free expression in artistic discourse.

\section{APPROPRIATION AND INFringement IN the Visual ARts}

Visual artists incorporate photographs and advertisements from diverse sources for use as referents within an original work. Such visual expression depends upon the duplication of previously copyrighted images. Because the viewer identifies and relates to familiar symbols, the appropriated images add content and context to the artist's commentary.

The appropriated images incorporated into visual art may serve to rep-

1. Copyright doctrine is codified in 17 U.S.C. $\S \S 101-118$ (1982).

2. Infringement refers to a breach of the exclusive rights of ownership granted a copyright owner under 17 U.S.C. $\S 106$ (1982). 
resent and document certain cultural norms. For example, a photograph of middle-aged, white policemen may symbolize state power and authority. ${ }^{3}$ The artist may challenge our conceptions of the legitimacy of this authority by juxtaposing this photograph with a news photo depicting black protesters injured by police during a race riot. ${ }^{4}$ The artist is commenting on the values represented by the component images; the appropriated photographs serve to document the norms which the artist is criticizing.

\section{A. Appropriating Art Forms}

A discussion of several contemporary art forms will illustrate the critical relation of appropriation to emerging forms of critical discourse.

\section{Static Art Forms}

Appropriation is a structural element of the montage genre in contemporary art. ${ }^{5}$ Montage artists incorporate previously published images into their own work of art as allegorical elements that enrich an artistic statement. ${ }^{6}$ For example, a photograph depicting a scene of the Vietnam War adds expressive content to a work which seeks to comment on militarism and aggression in contemporary society. ${ }^{7}$ The addition of the photograph makes the montage itself journalistic; ${ }^{8}$ it imposes a view of reality that adds meaning to the artistic conceit.

\section{Video Art}

The artist Dara Birnbaum's works provide an example of the use of appropriation in video art. She employs television footage from situation

3. See Morris, When Artists Use Photographs: Is It Fair Use, Legitimate Transformation or RipOff?, 80 ARTNEws 102, 105 (1981) (discussing Andy Warhol's "Race Riot" series).

4. Id.

5. "Montage" refers to an artistic composite of juxtaposed, heterogeneous images. The process of montage incorporates the allegorical elements of confiscation, superimposition, and fragmentation. Buchloh, Allegorical Procedures: Appropriation and Montage in Contemporary Art, 21 ARTFORUM 43 (1982).

6. An example of a montage work, Quarter Mile Piece, by Rauschenberg (scheduled for completion in 1984), "presents a tumult of words and images transferred from magazines, ads, and all sorts of printed matter." Kotz, Robert Rauschenberg's State of the Universe Message, 82 ARTNEws 54, 58 (1983).

7. For a discussion of Currents Study No. 7, see SmIthsonian InSTITUTE, Rauschenberg (1976).

8. Rauschenberg incorporates media images in his work in order to provide a comment on current events: "I have ... transformed these images ... as ingredients in . . . compositions which are dependent on reportage of current events and elements in our current environment, hopefully to give the work the possibility of being reconsidered and viewed in a totally new context." Morris, supra note 3, at 104; sep Kotz, supra note 6, at 63. Any restriction on the use of the incorporated images would result in suppression of artistic commentary. 
comedies and soap operas in her video works. ${ }^{9}$ Displaying a series of these images in isolation, Birnbaum attempts to critically deconstruct ${ }^{10}$ the structure of television programs to reveal their ideological function. ${ }^{11}$ Through this technique, she isolates instances where television reflects, and thus tends to propagate, cultural stereotypes.

Implicit in the Birnbaum genre is the conception that television exemplifies the perspective of mass culture. Video images therefore provide an essential resource for identification and analysis of society's ideological constructs. ${ }^{12}$ Again, the artist depends upon appropriated images to add substantive content to her commentary.

\section{Video and Film Documentaries}

Documentaries in film and video similarly depend upon the appropriation of visual images in order to convey critical expression. For example, the film "Killing Us Softly"13 appropriates segments from numerous commercials filmed off broadcast television in order to criticize depictions of women in advertising. The film asserts that advertising creates a sense of inadequacy in female consumers through depictions of housewives' failures and portrayals of an unrealistic ideal.

The advertisements imply women can overcome their failings through conscientious use of the sponsor's product. The filmmaker required exact reproductions of advertisements to point out nuances of meaning, conveyed through speech and facial expression, which document her study. ${ }^{\mathbf{1 4}}$

9. See Buchloh, supra note 5, at 54-56. The work of Tom Leeser and Diana Wilson provides a further example of video-collage which transforms appropriated information into a vehicle for aesthetic meaning. In their work Madam Mao's Lost Love Letters, a video image of Madame Mao with superimposed interference symbols is displayed while a recording of a poem and a list of political catchwords is played. The work established an intersubjective unity between the romantic and the political. See Running Dogs, Surveying Collage, 14 ARTweek 6 (1983).

10. See Cowan, Walter Benjamin's Theory of Allegory, 26 New German Critique 109, 112 (1982).

11. Buchloh, supra note 5 , at 56 .

12. See id. at 54 (Birnbaum uses material that "embodies collective perceptual experience").

13. Sep id. at 54 .

14. For example, the filmmaker includes an advertisement for a new, smaller size box cake which consists of a homemaker placing down a huge cake on the dinner table while her family looks dismayed and distraught that she made too large a dessert. The expressions of father and children indicate that the homemaker has somehow failed them because she did not use a product such as the one being advertised. 


\section{B. Absence of Legal Standard's Chilling Effect on Speech Interests in the Visual Arts}

Visual artists use appropriation as an allegorical device ${ }^{15}$ to convey expression. ${ }^{16} \mathrm{~A}$ copyright may, however, act to remove the required, appropriated image from the public realm, thus leaving the artist vulnerable to an infringement suit. ${ }^{17}$

Infringement actions have been brought against contemporary artists, such as Robert Rauschenberg, Larry Rivers, and Andy Warhol, ${ }^{18}$ for incorporating previously published images into their own works of art. As these cases invariably settle before trial, the boundaries of an artist's right to incorporate visual material remain unclear. ${ }^{10}$ The possibility of future challenges to artistic license therefore remains.

The absence of a definite legal standard for appropriation of visual images results in a chilling of freedom of speech interests. Artists will hesitate to experiment with creative modes if such experimentation may result in liability for copyright infringement. ${ }^{20}$ It is foreseeable that technological advances will increase the importance of visual modes of com-

15. Allegorical device refers to a method of symbolic representation. See infra note 70; Buchloh, supra note 5.

16. While similar appropriating acts for the purpose of expression may occur in the performing arts-such as dance and pantomime-a discussion of speech interests related to such works is beyond the scope of this Note.

17. The copyright statute provides that a copyright owner has "exclusive" rights to the following:

(1) to reproduce the copyrighted work in copies or phonorecords;

(2) to prepare derivative works based upon the copyrighted work;

(3) to distribute copies or phonorecords of the copyrighted work to the public by sale or

other transfer of ownership, or by rental, lease, or lending;

(4) in the case of literary, musical, dramatic, and choreographic works, pantomimes, and

motion pictures and other audiovisual works, to perform the copyrighted work publicly; and

(5) in the case of literary, musical, dramatic, and choreographic works, pantomimes, and

pictorial, graphic, or sculptural works, including the individual images of a motion picture or

other audiovisual work, to display the copyrighted work publicly.

17 U.S.C. $\$ 106$ (1982). The courts have held, however, that the grant of "exclusive rights" does not mean a complete monopoly. See, e.g., Fortnightly Corp. v. United Artists Television, Inc., 392 U.S. 390, 393-95 (1968) (copyright holder's rights limited to those enumerated by statute); Fawcett Publications, Inc. v. Elliot Publishing Co., 46 F. Supp. 717 (S.D.N.Y. 1942) (copyright protection not extended to owner seeking to prevent second-hand sale of copyrighted comic books); B. KAPLAN, AN UNHURRIEd ViEw of Copyrighr 57 (1967) ("The fundamental [is] that 'use' is not the same thing as 'infringement', that use short of infringement is to be encouraged . . .."). Non-infringing use is denominated "fair use." See infra note 35 .

18. In September 1980, Robert Rauschenberg reached a settlement with commercial photographer Morton Beebe in connection with Rauschenberg's incorporation of Beebe's photograph, entitled Diver, into a print from the artist's Hoarfrost series. Larry Rivers settled with photographer Amold Newman following publication of River's print Homage to Picasso, which incorporates a section of Newman's photographic portrait of Picasso. Similarly, Andy Warhol has given copies of his work to photographers who threaten to bring lawsuits over the incorporation of their work in Warhol's silkscreens. Morris, supra note 3, at 103-05.

19. These cases have been settled out of court, probably due as much to the artists' suspicion that the law does not serve their aims as to their stated desire to avoid legal costs. See Morris, supra note 3 , at 104 .

20. See id. at 106. 
munication. ${ }^{21}$ In order to protect these emerging forms of discourse, the law should expand protection of speech interests beyond current statutory limits. ${ }^{22}$

\section{The Inadequacy of GurRent Copyright Doctrine}

A tension clearly exists between copyright's grant of exclusive rights of authorship and First Amendment interests in wide dissemination of ideas. ${ }^{23}$ Copyright law contains two statutory limitations which attempt to accommodate speech interests. These principles, however, fail to provide a relevant analysis for infringement of visual material, thus leaving unprotected important speech interests of appropriating artists.

\section{A. Idea-Expression Dichotomy}

A central tenet of copyright law is that an idea may not be copyrighted, but a particular expression of that idea is subject to protection. ${ }^{24}$ Ideas

21. See Buchloh, supra note 5, at 54 (according to video artist Nam June Paik, "visual culture [will] be contained in and affected by the emergence of television as the primary social practice of visual meaning production").

Commercial, electronic teletext and videotext systems currently under development will increase the range of visual displays of information on individual home television sets. See Note, Toward a Unified Theory of Copyright Infringement for an Advanced Technological Age, 96 HARv. L. REv. 450, 452 (1982).

22. Cf. Copyright Law Revision: Hearings Before the Senate Comm. on the Judiciary, 89th Cong., 1st Sess., 24 (1961) (statement of Register of Copyrights) (copyright statute must respond to technology based on instant communication); Merryman, The Refrigerator of Bernard Buffet, 27 Hastings L.J. 1023, 1042 (1976) ("American art has achieved international recognition only in the last two decades; what has been rather lyrically called 'the triumph of American Art' is a very recent phenomenon. Legal change usually lags behind social and cultural change."); Nimmer, Does Copyright Abridge the Guarantees of Free Speech and Press?, 17 UCLA L. Rev. 1180, 1204 (1970) (technological advances require rethinking the place of copyright and scope of First Amendment).

23. The First Amendment reads: "Congress shall make no law ... abridging the freedom of speech." U.S. CONST. amend. I.

In Williams \& Wilkins Co. v. United States, 487 F.2d 1345 (Ct. Cl. 1973), the court noted a conflict between copyright and dissemination of ideas: "[T]he development of 'fair use' has been influenced by some tension between the direct aim of the copyright privilege to grant the owner a right from which he can reap financial benefit and the more fundamental purpose of the protection "To promote the Progress of Science and the useful Arts." "). Id. at 1352. It has similarly been noted:

Copyright properly understood and wisely handled may be at the same time a powerful stimulus to creation and the means of opening the channels of dissemination of thought, information, and debate. Misunderstood, and with its true purpose lost sight of, copyright can become a limitation on creation and a barrier to free exchange and expression.

Evans, Copyright and the Public Interest, 2 UNESCO COPYRIGHT BuLL. 2 (1949).

24. The copyright statute restates the idea-expression dichotomy: "In no case does copyright protection for an original work of authorship extend to any idea, procedure, process, system, method of operation, concept, principle, or discovery, regardless of the form in which it is described, explained, illustrated, or embodied in such work." 17 U.S.C. \$102(b) (1982) (emphasis added); see also Mazer v. Stein, 347 U.S. 201, 217 (1954) ("[a] Copyright gives no exclusive right to the art disclosed; protection is given only to the expression of an idea-not the idea itself').

The idea-expression dichotomy is the basis of Judge Learned Hand's "patterns" or "abstractions" test, articulated in Nicholas v. Universal Pictures Corp., 45 F.2d 119 (2d Cir. 1930):

Upon any work ... a great number of patterns of increasing generality will fit equally well, 
remain in the public realm to ensure free access to information; ${ }^{25}$ expressions of ideas are subject to copyright in order to reward their creators. ${ }^{26}$

Applying the idea-expression test to a pictorial work, the "idea" serves as the equivalent of the iconographic content ${ }^{27}$ represented in the picture. The use of thematic material would be protected since it encompasses an idea in the public realm. ${ }^{28}$

The idea-expression dichotomy proves more difficult to apply to nonrepresentational art. For example, Josef Albers, a leader in the movement to abstraction, confined iconographic content in his paintings to the square; the form provided simplicity and stability, allowing Albers to explore the potential of color combinations. ${ }^{29}$ It becomes difficult to identify the idea in such works. Technique merges with form, and it becomes clear

.. . but there is a point in this series of abstractions where they are no longer protected, since otherwise the [copyright owner] could prevent the use of his ideas, to which, apart from their expression, his property is never extended.

Id. at 121. Hand emphasized that the selection and arrangement of ideas in a work may receive copyright protection, depending upon the level of abstraction of the idea presented. For example, if a story is comprised solely of a formula plot with stock characters, the ideas are too abstract to be accorded copyright protection. Sep id.; see also Peter Pan Fabrics, Inc. v. Martin Weiner Corp., 274 F.2d 487 (2d Cir. 1960) (fabric designer who altered copyrighted design infringed where disparities from original pattern were not obvious to ordinary observer).

The idea-expression dichotomy does not provide the visual artist with any degree of certainty in application:

Obviously, no principle can be stated as to when an imitator has gone beyond copying the

"idea," and has borrowed its "expression." Decisions must therefore inevitably be ad hoc. In the case of designs, which are addressed to the aesthetic sensibilities of an observer, the test is, if possible, even more intangible . . . . [O]ne cannot say how far an imitator must depart from undeviating reproduction to escape infringement. Id. at 489 .

25. See Sid \& Marty Krofft Television Prods., Inc. v. McDonald's Corp., 562 F.2d 1157, 1170 (9th Gir. 1977) ("The 'marketplace of ideas' is not limited by copyright because copyright is limited to protection of expression.").

26. The Supreme Court has stated that the primary purpose of copyright is to benefit the public by encouraging creative productivity. See Mazer v. Stein, 347 U.S. 201, 219 (1954). Thus the reward granted a copyright owner is an incidental means to secure public benefits. See also Twentieth Century Music Corp. v. Aiken, 422 U.S. 151, 156 (1975) ("private motivation must ultimately serve the cause of promoting broad public availability of literature, music, and the other arts"); $1 \mathrm{M}$. NIMMER, NIMMER ON COPYRIGHT $\S 1.03[\mathrm{~A}]$ at 1-29 (1983) ("[C]opyright is predicated upon the dual premises that the public benefits from the creative activities of authors, and that the copyright monopoly is a necessary condition to the full realization of such creative activities.").

27. Iconographic content refers to the imagery seeking to convey meaning in a work of art. It describes the subject matter or theme of a work as opposed to its form. See E. Panofsky, Meaning IN THE VISUAL ARTS 26-30 (1955).

28. The history of Western art is replete with recurring themes which an artist is free to use. For example, the rape of the Sabine women is a theme represented in works by Titian, Reubens, and Picasso. Although the idea presented in each of these paintings is the same, the expression of the theme is clearly unique to each work. See B. KAPLAN, supra note 17, at 56 ("If standard works like David's Rape of the Sabines, which Picasso recently chose to redo, were under copyright, not only would Picasso fail to infringe, he would, I think, be nearly incapable of doing so even if he put his mind to it."). Similarly, Picasso's 1937 self-portrait copied an earlier self-portrait by Poussin, in that Picasso portrayed himself in the exact pose and carrying the same implements as did Poussin. Though the idea in the paintings is the same, the expressions of the same concept are completely different.

29. See D. Mendelowitz, A History of AMerican ART 435 (2d ed. 1970). 
that the form, or idea, is of little value when divorced from its expression. $^{30}$

The relevant analytic distinctions in the idea-expression test fail completely when applied to montage. In this circumstance, the artist appropriates the exact expression of an idea; he has adapted it, however, changing its character in the context of an independent artistic creation. ${ }^{31}$ The artist incorporates the appropriated work into a separate expressive form that is dependent upon, but not limited by, its past mode of expression. The resulting product is not a mere copy which we may legitimately prohibit, but an entirely new expression which the law should serve to protect. ${ }^{32}$

The idea-expression dichotomy similarly fails to rationally delineate permissible contours of appropriation in film and video commentary. Documentaries, such as "Killing Us Softly,"33 appropriate visual images for their evidentiary worth as well as their substantive content. Just as literary critics depend on textual examples to illustrate a theory, critics of visual media need to duplicate images in order to document their observations. It would be possible to describe or simulate the content of appropriated images, but such technique would lessen the impact and insight of a critical study. ${ }^{34}$

\section{B. The Fair Use Defense}

The most important statutory device for accommodating speech interests is the defense of "fair use." 35 Fair use permits infringement within the

30. In at least one instance, a court has upheld infringement of a visual artwork where the idea was inseparable from its expression. See Herbert Rosenthal Jewelry Corp. v. Kalpakian, 446 F.2d 738 (9th Cir. 1971) (jeweler permitted to sell jewel-encrusted pin in shape of bee despite fact that similar, copyrighted piece existed).

31. See H. Blocker, Philosophy of ART 23 (1978) ("[T]he autonomous quality of the art work creates a new point of view, internal to the art work, which, at the same time, sheds light back on to the real world.").

32. A montage does not fit comfortably into any of the defined categories of works accorded copyright protection. It perhaps comes closest to the category of "compilations"- "the collection and assembling of pre-existing materials . . . [that] constitutes an original work of authorship." 17 U.S.C. $\S$ 101 (1982). But while this definition accurately describes the procedure involved in creating a montage work, it does not take into account the conceptual structure superimposed by the infringing artist which reflects the speech interest in the work. Rather than creating a collection of similar material, the artist is juxtaposing contrasting images with the intent to make an artistic statement.

33. See supra pp. 1567-69.

34. Nimmer comments on the difficulty of simulating a photograph:

To attempt a simulated photograph with models posing as dead bodies in order to express the idea of the original My Lai photographs would be ludicrous. The expression must be copied along with the idea not because it is onerous for an idea copier to create his own expression, but rather because the idea cannot be conveyed unless the expression as well is copied.

Nimmer, supra note 22, at 1203.

35. One definition of fair use is "a privilege in others than the owner of the copyright to use the copyrighted material in a reasonable manner without his consent, notwithstanding the monopoly granted to the owner by the copyright." H. Bal., The Law of Copyright and Literary PropERTY 260 (1944). 
scope of the limited category of uses that Congress has chosen to promote. For example, the defense protects use of copyrighted materials for scientific or educational purposes. ${ }^{36}$ Three tests have developed in case law to determine instances of a fair use: (1) substantial similarity of material; (2) commercial character of use; and (3) competitive effect of use of copyrighted material. ${ }^{37}$ These tests also fail to establish relevant limitations on the use of visual images in critical discourse. ${ }^{38}$

\section{Substantial Similarity}

The existence of substantial similarity and "access" to a work creates a prima facie case of infringement. ${ }^{39}$ As a corollary to this doctrine, any

The 1976 Copyright Law revision transformed the common law defense of "fair use" into a statutory right:

Notwithstanding the provisions of section 106, the fair use of a copyrighted work, including such use by reproduction in copies or phonorecords or by any other means specified by that section, for purposes such as criticism, comment, news reporting, teaching (including multiple copies for classroom use), scholarship, or research, is not an infringement of copyright. In determining whether the use made of a work in any particular case is a fair use the factors to be considered shall include:

(1) the purpose and character of the use, including whether such use is of a com-

mercial nature or is for nonprofit educational purposes;

(2) the nature of the copyrighted work;

(3) the amount and substantiality of the portion used in relation to the copyrighted work as a whole; and

(4). the effect of the use upon the potential market for or value of the copyrighted work.

17 U.S.C. § 107 (1982).

Although "fair use" tests attempt to identify the criteria that allow legitimate use of copyrighted material, the concept has been referred to as "exceptionally elusive even for the law." Marvin Worth Prods. v. Superior Films Corp., 319 F. Supp. 1269, 1273 (S.D.N.Y. 1970). Another statutory accommodative device is the requirement that copyright subsist for only a limited duration. 17 U.S.C. $\$ 302$ (a) (1982) ("Copyright in a work created on or after January 1, 1978, subsists from its creation and .... endures for a term consisting of the life of the author and fifty years after the author's death.").

36. 17 U.S.C. $§ 107$ (1982).

37. Id. The fair use provision provides for examination of the "nature of the copyrighted work" as well. This factor primarily is used to show a preference for scientific, educational and charitable purposes. It has not been transformed into a distinct fair use test.

38. Despite the restrictive quality of the fair use defense, the legislative history of the copyright statute suggests that Congress intended the defense to be a flexible doctrine able to provide for emerging forms of creative discourse:

The statement of the fair use doctrine in section 107 offers some guidance to users in determining when the principles of the doctrine apply. However, the endless variety of situations and combinations of circumstances that can arise in particular cases precludes the formulation of exact rules in the statute. The bill endorses the purpose and general scope of the judicial doctrine of fair use . . . but there is no disposition to freeze the doctrine in the statute, especially during a period of rapid technological change. Beyond a very broad statutory explanation of what fair use is and some of the criteria applicable to it, the courts must be free to adapt the doctrine to particular situations on a case-by-case basis. Section 107 is intended to restate the present judicial doctrine of fair use, not to change, narrow, or enlarge it in any way. H.R. REP. No. 1476, 94th Cong., 2d Sess. 55-56 (1976); S. REP. No. 473, 94th Cong., 1st Sess. 62 (1975).

39. See generally, Scott v. WKJG, Inc., 376 F.2d 467, 469 (7th Cir. 1967) (infringement decided by inquiry into access and similarity); MacDonald v. DuMaurier, 75 F. Supp. 655, 657 (S.D.N.Y. 
similarity not substantial is not an infringement. ${ }^{40}$ This defense clearly is not available to the artist employing appropriation of visual images as a vehicle for expression. The images appropriated for use in montage, for example, are necessarily identical to images in the final work, and a fair use defense is rarely available to immunize copying which is virtually complete. ${ }^{41}$ Thus, while the substantial similarity test protects written expression which may restate copyrighted material in a different form, it fails to protect visual forms of speech where the mode of expression is essential to the idea expressed.

The vital distinction between visual and written speech concerns the inability to impart a visual image without access to its exact expression. ${ }^{\mathbf{2}}$ A writer may quote or paraphrase written speech, thus allowing for expression of the ideas contained in the borrowings. In contrast, a visual artist may not quote or explain visual speech and still preserve its exact meaning. ${ }^{13}$ Thus, a prohibition on the use of visual speech results in a total prohibition of expression involving appropriations of copyrighted images.

\section{Commercial Character of Use}

According to present judicial doctrine, the scope of fair use in a commercial context is narrower than in the realm of non-profit activity. ${ }^{44}$

\section{8) (same).}

Courts have stated that proof of both actual viewing and knowledge of the copyrighted work is necessary to show access. See Christie v. Harris, 47 F. Supp. 39, 40 (D.N.Y. 1942) (infringement proven by actual copying made possible by access to the copyrighted material). But see Smith v. Little, Brown \& Co., 245 F. Supp. 451, 458 (S.D.N.Y. 1965) (copying proven by circumstantial evidence of access and similarities to protected work) $3 \mathrm{M}$. NIMMER, NIMMER ON COPYRIGHT § 13.02[A], at 139 (1983) (access requires only proof of reasonable opportunity to view).

40. See Meredith Corp. v. Harper \& Row Publishers Inc., 378 F. Supp. 686 (S.D.N.Y. 1974).

41. See Walt Disney Prods. v. Air Pirates, 581 F.2d 751, 756 (9th Cir. 1978) (substantial copying of identifiable cartoon characters acted as bar to invoking fair use defense); Nimmer, supra note 22, at 1192.

42. See Nimmer, supra note 22, at 1197 ("To the extent that a meaningful democratic dialogue depends upon access to graphic works generally . . . it must be said that little is contributed by the idea divorced from its expression.").

43. "[A] work of art cannot be described but can only be experienced." Triangle Publications, Inc. v. Knight-Ridder Newspapers, Inc., 626 F.2d 1171, 1181 (5th Cir. 1980) (Brown, J., dissenting) (citing $1 \mathrm{M}$. NIMMER, supra note 26, \$1.10 [c][2], at 1-81 (1978)).

44. SeP e.g., Henry Holt \& Co. v. Liggett \& Myers Tobacco Co., 23 F. Supp. 302 (E.D. Pa. 1938) (court barred fair use defense due to defendant's commercial purpose in using copyrighted material); Loew's Inc. v. Columbia Broadcasting Sys., Inc., 131 F. Supp. 165 (S.D. Cal. 1955), aff'd sub nom. Benny v. Loew's, Inc., 239 F.2d 532 (9th Cir. 1956), aff'd, 356 U.S. 43 (1958) (scope of fair use is narrowed in commercial realm); H.R.REP. No. 1476, 94th Cong., 2d Sess. 66 (1976) ("[U]nder the present law, the commercial and non-profit character of an activity, while not conclusive with respect to fair use, can and should be weighed along with other factors in fair use decisions."), reprinted in 1976 U.S. CODE CoNG. \& AD. NEws 5569, 5679. But cf. Rosemont Enter., Inc. v. Random House, Inc., 366 F.2d 303, 307 (2d. Cir. 1966) ("Whether an author . . . is motivated in part by a desire for commercial gain, or whether [his publication] is designed for the popular market ... has no bearing on whether a public benefit may be derived from such a work ...."). 
While the commercial purpose served by an appropriation is not conclusive, a court will weigh this factor in determining the existence of fair use. 45

The visual artist would probably be unable to meet the requisite nonprofit criterion; therefore the possibility of a fair use defense is, to some extent, diminished. ${ }^{48}$ Because visual art works represent a significant investment of time and resources, artists will probably choose to recoup their investment by selling their works. ${ }^{47}$

\section{Effect of Use on the Market for Copyrighted Work}

Another test of fair use examines the effect of the use of copyrighted material upon the market for the appropriated work. ${ }^{48}$ If such use dilutes the market for, or decreases the value of, the copyrighted work, that use is a copyright infringement.

The purpose of this economic inquiry is to ferret out instances of direct economic competition. ${ }^{40}$ Therefore, it should not act to deter critical, visual works which do not directly compete with the images they incorporate. The analysis may, however, affect the visual artist whose commentary arguably has an indirect, negative impact upon the value of the component images. It would be difficult to measure the economic impact resulting from inclusion of a vacuum-cleaner advertisement in a Rauschenberg collage. ${ }^{\mathrm{s0}}$ Yet if the collage could be interpreted as criticizing consumer values, it might be equally difficult to argue that the use had no effect upon the value of the underlying ad.

According to the fair use provision, courts may consider this effect of the use upon the potential value of the copyrighted material when determining infringement. ${ }^{51} \mathrm{~A}$ stricter showing of negative economic effect is necessary in order to protect rights of free expression.

45. 17 U.S.C. $\$ 107 .(1)$ (1982) states that a consideration in permitting a fair use defense is whether copying is "of a commercial nature or is for nonprofit, educational purposes."

46. See, e.g., Triangle Publications, Inc. v. Knight-Ridder Newspapers, Inc., 626 F.2d 1171, 1175 (5th Cir. 1980) ("any commercial use tends to cut against a fair use defense"); 3 M. NIMMER, supra note $39, \S 13.05[\mathrm{~A}]$ at $13-61$ (fair use more readily recognized where work demonstrates educational, scientific purposes).

47. In contrast, a First Amendment defense would protect expression despite its commercial nature. See, e.g., Bigelow v. Virginia, 421 U.S. 809, 826 (1975) ("The relationship of speech to the marketplace of products or of services does not make it valueless in the marketplace of ideas."); Time, Inc. v. Hill, 385 U.S. 374, 396-97 (1967).

48. See, e.g., MCA, Inc. v. Wilson, 677 F.2d 180 (2d Cir. 1981); Time, Inc. v. Bernard Geis Assocs., 293 F. Supp. 130 (S.D.N.Y. 1968).

49. 3 M. NIMMER, supra note $39, \S 13.05$ [A][4], at 13-65.

50. See infra note 67 (describing Currents Study No. 7).

51. Id. 


\section{The Inadequacy of Current First Amendment Doctrine}

Recognizing that fair use offers inadequate protection of beneficial uses of copyrighted materials, courts and commentators have recommended a First Amendment defense to infringement actions. ${ }^{52}$

\section{A. Judicial Recognition of First Amendment Interests}

Courts have recognized that fair use encompasses a limited constitutional dimension. ${ }^{53}$ The court in Time, Inc. v. Bernard Geis Associates ${ }^{54}$ upheld an author's use of stills from the Zapruder films of President Kennedy's assassination. The author included the photographs in his own study in order to criticize the government's investigation of the incident and to document an alternative theory.

In affirming the unauthorized use of the copyrighted photographs, which Zapruder had sold to Time magazine, the court imposed a novel "public interest in full information" standard. ${ }^{\text {s5 }}$ It also recognized a critic's right to appropriate exact expression which helps to clarify or document a study. ${ }^{\circ 8}$ The court stated: "While doubtless the theory could be explained with sketches . . . the explanation actually made in the Book with copies is easier to understand." "37

Although the Time case provides a precedent for recognition of a First Amendment defense to infringement actions, courts have been unwilling to apply the "public interest" rationale to discourse of less obvious public import. $^{\text {s8 }}$

52. See Nimmer, supra note 22; Sobel, Copyright and the First Amendment: A Gathering Storm?, 19 ASCAP Copyright L. SYMP. 43 (1971); Note, The First Amendment Exception to Copyright: $A$ Proposed Test, 1977 Wisc. L. Rev. 1158.

53. In Rosemont Enters., Inc. v. Random House, Inc., 366 F.2d 303 (2d cir. 1966), the court set forth a "public interest" standard for infringement in the context of use of written, rather than visual, works. In order to hinder writers' efforts to document his life, Howard Hughes formed a corporate entity to acquire copyrights to magazine articles written about him. The court affirmed an author's right to make use of information contained in the articles:

The spirit of the First Amendment applies to the copyright laws at least to the extent that the courts should not tolerate any attempted interference with the public's right to be informed regarding matters of general interest when any one seeks to use the Copyright Statute which was designed to protect interests of quite a different nature.

54. 293 F. Supp. 130 (S.D.N.Y. 1968).

55. Id. at 146; see also Rosemont Enters., Inc. v. Random House, Inc., 366 F.2d 303, 309 (2d Cir. 1966) ("'Everyone will agree that at some point the public interest in obtaining information becomes dominant over the individual's desire for privacy." (quoting Sidis v. F-R Pub. Corp., 113 F.2d 806, 809 (2d Cir.), cert. denied, 311 U.S. 711 (1940)).

56. See supra TAN 13-14.

57. Time 2. Bermard Geis, 293 F. Supp. at 146.

58. See, e.g., Walt Disney Prods. v. Air Pirates, 345 F. Supp. 108 (N.D. Cal. 1972) (court refused to consider cartoon parodist's First Amendment defense without an express allegation of interference with public's right to be informed); United States v. Bodin, 375 F. Supp. 1265 (W.D. Okla. 1974) (First Amendment not considered where infringers copied sound recordings without attempting to add artistic expression).

Courts sometimes strike down First Amendment defenses as frivolous. See, e.g., id. (bootlegged 
In Triangle Publications, Inc. v. Knight-Ridder Newspapers, Inc., the Fifth Circuit reversed a ruling that the First Amendment protected the display of a copyrighted image when used for purposes of comparative advertising. The plaintiff-publisher introduced a Sunday supplement television guide through television and newspaper ads that included a reproduced cover of a competitor publication-T.V. Guide. The district court held that the commercial character of the use barred invocation of a First Amendment defense, but nevertheless found the public interest served by dissemination of consumer information sufficient to warrant a First Amendment defense. ${ }^{80}$

Although the circuit court upheld plaintiff's display of the cover as fair use, it decided the case on an interpretation of fair-use factors rather than on reliance upon a public interest rationale. Central to its holding was precedent that the commercial nature and purpose of the publication was not dispositive; $;$ the appropriation was not "substantial" as the "essence" or content of the copyrighted work was not taken;, economic detriment to defendant was de minimus since any effect on the value of plaintiff's interest resulted from the nature of advertising itself, ${ }^{63}$ and the defendant failed to show a causal link between the infringement and resulting economic harm.

The Triangle case provided an opportunity to apply a First Amendment standard to a legitimate borrowing of visual images. Because the decision rested instead on cursory application of fair use standards, the availability of a First Amendment defense remains uncertain. ${ }^{64}$

tapes not protected because First Amendment was not intended to protect infringement of copyright); McGraw-Hill, Inc. v. Worth Publishers, Inc. 335 F. Supp. 415, 422 (S.D.N.Y. 1971) (defendant's First Amendment argument for borrowing texthook segment "dismissed as flying in the face of established law").

Courts may even recognize speech interests through fair use to avoid reaching First Amendment issues. See, e.g., Italian Book Corp. v. American Broadcasting Co., 458 F. Supp. 65 (S.D.N.Y. 1978) (since fair use encompasses right of television news program covering parade to broadcast one of band's numbers, court declined to reach constitutional question); Keep Thomson Governor Comm. v. Citizens for Gallen Comm., 457 F. Supp. 957, 960 (D.N.H. 1978) (political committee's use of segment from song was fair use; court did not reach First Amendment defense).

59. 626 F.2d 1171 (5th Cir. 1980).

60. 445 F. Supp. 875, 882 (S.D. Fla. 1978) ("When the Copyright Act and the First Amendment both seek the same objective, their future coexistence is easily assured. However, when they operate at cross-purposes, the primacy of the First Amendment mandates that the Copyright Act be deprived of effectuation.").

61. 626 F.2d at $1175-76$.

62. Id. at 1177. The court avoided the obstacle of applying the "substantial similarity" test to an exact visual reproduction by holding that defendant's copyright extended to the publication as a whole and that the cover picture was not independently copyrighted.

63. Id. at $1177-78$.

64. The Triangle Court consciously avoided reaching the constitutional dimension of fair use. In his concurring opinion, however, Judge Tate stated: "[U]nder limited circumstances, a First Amendment privilege may, and should exist where utilization of the copyrighted expression is necessary for the purpose of conveying thoughts or expression." Id. at 1184 (emphasis in original). 


\section{B. Nimmer's Recognition of First Amendment Interests}

Commentators have generally ignored the question of appropriation in the visual arts or have specifically dismissed visual material as not requiring First Amendment protection. Melville Nimmer, a leading copyright authority, would extend First Amendment protection based on the public's right to receive information to infringement of a category he describes as "news photos." Nis Nimmer suggests that news photos of the My Lai massacre, for example, reveal a truth that could not be fully evidenced in text. ${ }^{\circ 8} \mathrm{He}$ concludes, however, that generally appropriation of visual images is justifiably restricted, since art lacks political significance in comparison to written materials. ${ }^{67}$

In his attempt to restrict the scope of a First Amendment defense, Nimmer has ignored the significance of the contribution of non-photographic visual arts to the marketplace of ideas. Nimmer would permit First Amendment protection of copyrighted photos of the My Lai massacre because of the public's interest in receiving such information. Under Nimmer's proposal, however, such protection apparently would not extend to Robert Rauschenberg's incorporation of a New York Times photograph of the My Lai incident in his work Currents Study No. $7 .^{88}$

\footnotetext{
65. As Nimmer explains:

[News p]hotographs would refer to all products of the photographic and analogous processes, including motion picture film and video tape, but would exclude other graphic works, such as paintings, sculptures, etc. The public interest in the latter works are usually because of the creative contribution of the artist, and not because of the factual content which they convey.

Nimmer, supra note 22, at 1199 . In addition, Nimmer suggests the event depicted in the photograph need be the subject of nationwide news stories to qualify as a news photo. Id.

66. Id. at 1192 .

67. As Nimmer posits:

Admittedly, the democratic dialogue gains little from free access to graphic work ideas divorced from expression. But even were the speech value of free access to graphic work expressions to be weighted against the copyright value in encouraging the creation of such graphic works, the copyright interest would appear to prevail in most cases. The additional enlightenment contributed to the democratic dialogue by reason of the usual impact of most graphic works is relatively slight as compared with the intellectual impact of a literary work.
}

Id. at 1197.

68. Currents Study No. 7 is a graphic work created by Rauschenberg in 1970. It contains a collection of newspaper articles and photographs, including a photo of American servicemen entitled "My Lei, an American tragedy." Kotz, supra note 6, at 56-57. Despite its overt political message, Currents Study No. 7 would not receive protection advocated by Nimmer, who intentionally omits "graphic works, such as paintings, sculpture" from his news photo exception. See supra note 65.

Nimmer could argue that, once a photographer has disseminated his work, the idea has then entered the public realm and requires no additional protection. See, Note, supra note 52, at 1158. A collage which incorporates an extant news photograph, however, manifests a unique form of expression; the infringing artist creates a context for the news photo that alters the meaning conveyed by the photograph alone. This new form of expression informs the public and is of no less public interest than an isolated photograph of the incident. The art work may, in fact, be a more poignant, compelling expression of an idea, as the artist has imposed an aesthetic and historic context on the work. Nimmer's news photo test fails to protect such political and artistic expression due to the limitations inherent in his definition of "news photo."

Another attempt to expand the "public interest in free dissemination of information" doctrine oc- 


\section{An Expanded First Amendment Defense}

As the visual arts perform an increasingly widespread role in political as well as artistic discourse, the potential for damage from censorship through copyright increases. Visual art contributes to the political dialogue, and is thus deserving of First Amendment protection.

\section{A. Appropriation as a Political Statement}

Visual art works which appropriate news photos further political discussion at two levels. First, many of the images conveyed in artistic discourse are photographic representations of racism, militarism, or consumerism. ${ }^{6}$ The message conveyed is overtly political. Because political discourse lies at the very core of First Amendment concerns, ${ }^{70}$ these images deserve the status of protected speech.

The process of appropriation itself acts as a political symbol. As a technique in critical discourse, appropriation defies the very structure that copyright serves to protect. It manifests a rejection of private property in favor of a more communitarian conception of society. Therefore, the act of appropriation itself imparts a political message; ${ }^{71}$ it reveals that society

curs in a proposed test which recognizes the utility of appropriation. See Note, supra note 52. The test consists of a two-step inquiry: Is the "base idea" of the infringing work protected speech? If so, can the "base idea" be expressed without use of the appropriated material?

Although this inquiry avoids the risk of unbridled judicial discretion, it would not protect the visual arts, since the base idea of an abstract work of video montage is not readily discernible. The test is clearly geared towards protection of written speech; its limitations are similar to those of the ideaexpression dichotomy.

69. For an example of such political commentary, see discussion of Rauschenberg Currents in Kotz, supra note 6 at 56-57. Of course, non-representational art also may evoke a political message. See generally A. Cox, ART-As-Polrtics (1982) (critics Harold Rosenberg and Clement Greenberg interpreted abstract expressionist painting in terms of political meaning).

70. "The First Amendment affords the broadest protection to . . . political expression in order to assure the unfettered interchange of ideas for the bringing about of political and social changes desired by the people." Keep Thomson Governor Comm. v. Citizens for Gallen Comm., 457 F. Supp. 957,

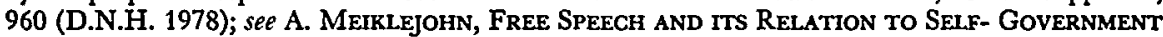
25 (1972); Emerson, Toward a General Theory of the First Amendment, 72 YALE L.J. 877, 883 (1963) ("Freedom of expression in the political realm is usually a necessary condition for securing freedom elsewhere. It is in the political sector, therefore, that the crucial battles over free expression are most often fought.").

71. See Buchloh, supra note 5, at 44-46 (Marxist interpretation of montage technique that reveals the political content inherent in works incorporating appropriated material).

Montage is an essentially allegorical product; the appropriated images serve as ideological correlates of private property. By the act of selection and incorporation, the artist attempts to re-invest objects with a value distinct from their commodity value in society-the assumption being that industrial society has devalued objects by transforming them into mere commodities. Objects, therefore, have lost an inherent, authentic value; market forces establish their worth. Montage serves to allegorically "redeem" the object by emphasizing its value as a unique visual symbol rather than a fungible commodity. Id. at 56 .

The Marxist perspective suggests that recognition of property rights is accompanied by a dilution of property value. By appropriating images, the artist rejects the commodity-value of the object and can therefore instill the object with new meaning. This artistic discourse conveys an implicit criticism of socio-economic structures that recognize property interests as an ultimate value. Cowan, supra note 
(and its legal system) is laden with assumptions that financial incentives promote individual creativity, and that property interests supercede society's right of access to ideas and information. ${ }^{72}$ The explicit, and somewhat random, incorporation of copyrighted objects into the artist's own creative work challenges the bias toward individual property interests. ${ }^{73}$

In addition, the act of appropriation supports communitarian values through its symbolic rejection of the "myth" of individual expression. By incorporating mass-produced images into creative works, the artist asserts that conceptions of individual expression, creativity, and genius are outmoded in a mass society. ${ }^{74}$

In order to challenge traditional assumptions of artistic individuation, the artist incorporates the images of another into his own work in a conscious attempt to produce a radical, communal discourse. ${ }^{76}$ Thus, the act of appropriation gives meaning to the expression embodied in the creative work; the mere simulation of images would reduce, if not eliminate, the

10 , at 122.

The speech value in an appropriating work need not be explicit to affect our political decisions:

[A] decision to disbelieve a message does not erase all the effects it may have on us. Even if I dismiss what is said or shown to me as foolish and exaggerated, I am slightly different for having seen or heard it. This difference can be trivial but it can also be significant and have a significant effect on my later decisions. For example, being shown powerful photographs of the horrors of war, no matter what my initial reaction to them may be, can have the effect of heightening (or ultimately of dulling) my sense of the human suffering involved, and this may later effect [sic] my opinions about foreign policy in ways I am hardly aware of.

Scanlon, Freedom of Expression and Categories of Expression, in FREEDOM OF ExpREssion 479 (K. Middleton ed. 1981); see also infra note 95 (distinguishing appropriation of visual images from appropriation of material goods.

72. In contrast, courts have held that freedom of expression encompasses the right both to convey and to receive information. See Kleindienst v. Mandel, 408 U.S. 753, 762-63 (1972); Red Lion Broadcasting Co. v. FCC, 395 U.S. 367, 390 (1969); Stanley v. Georgia, 394 U.S. 557, 564 (1969).

73. The Marxist aesthetic-as evidenced in montage works-seeks to establish a basis for an intersubjective unity of culture by defying culturally accepted norms regarding private property and artistic individuation. The artist's blatant disrespect for property rights contributes to a communitarian artistic statement. See Benjamin, The Work of Art in the Age of Mechanical Reproduction, in Illuminations 217 (H. Arendt ed. 1969). Benjamin expounds a theory, first proposed by Georg Lukacs, that the world of art reflects the cultural alienation of contemporary society. Just as the emergence of specialization in the workplace alienates the worker, the cultivation of isolation separates the artist from any possible unity of culture. Montage artists rebel against the values of appropriation and gesture towards a communitarian unity of culture.

74. The artist may challenge traditional conceptions of individual expression and creativity not only in the choice of subject matter but in the artistic process as well. For example, at Andy Warhol's Factory, a professional silkscreener may reproduce a photographic image, chosen by Warhol, on a canvas, while several people actually may work on the finished product. This rather communal arrangement acknowledges that art may be a product of a collective process rather than individual effort. See Morris, supra note 3, at 102; see also B. KaPLAN, supra note 17, at 118 ("Professor McLuhan . . . says broadly that as the imperium in communications passes from books to electronic manifestations, as the 'Gutenberg galaxy' decays, not only is the relationship between author and audience radically changed, but the author's pretensions to individual ownership and achievement are at a discount.") (citing M. McLuhan, The Gutenberg Galaxy: The Making of Typographic MAN (1962)).

75. Buchloh, supra note 5 at 48. (In post-modernist era, "any return to an unconditioned autonomy of art production would be mere pretense, lacking historical logic . . ..") 
impact of the expression. ${ }^{78}$ In order to protect such politically motivated expression, the law should accommodate the appropriation of reproduced images when used for expressive purposes. ${ }^{77}$

\section{B. Traditional First Amendment Protection of the Marketplace of Ideas}

The First Amendment defense presents an appropriate means to protect expression that depends upon the use of copyrighted visual images, but courts have been hesitant to recognize such far-reaching protection of speech..$^{78}$ Furthermore, traditional First Amendment interpretation fails to encompass the radical mode of speech represented by appropriating forms of discourse.

The marketplace-of-ideas rationale for permitting free expression disfavors unconventional speech that fails to conform to the requirements of a rational, democratic dialogue. A dialogue presupposes the existence of rational individuals, each competent to assert his own personal bias and to further his own interests, who form opinions on the basis of reasoned arguments. ${ }^{79}$ The assumption is that free debate will lead to a consensus that will benefit the majority. ${ }^{80}$

Freedom of expression ensures that the dialogue will continuously reflect changing perceptions of individual interests. The ongoing character of the debate provides impetus for measured change that promotes institutional stability ${ }^{81}$ Furthermore, freedom of expression provides a means to

76. See supra p. 1577.

77. In Rohauer v. Killiam Shows, Inc., 379 F. Supp. 723 (S.D.N.Y. 1974), cert. denied, 431 U.S. 949 (1977), the court rejected a defense to infringement of copyrighted material used in Lenny, a film based on the life of Lenny Bruce, because it found a lack of public interest in the subject matter. It is not unlikely that a court may similarly fail to see the public interest in an avant-garde work of art. Although the discourse may at times be inaccessible to the public at large, the issues raised by art works using conscious appropriation clearly are issues of public concern. See supra note 72.

78. See supra p. 1575.

79. See, e.g., Whitney v. California, 274 U.S. 357, 375-76 (1927) (Brandeis, J., concurring) ("[F]reedom to think as you will and to speak as you think are means indispensable to the discovery and spread of political truth .... Believing in the power of reason as applied through public discussion, [the Founders] eschewed silence coerced by law . . . ."); Milk Wagon Drivers Local 753 v. Meadowmoor Dairies, 312 U.S. 287 (1941) ("It must never be forgotten . . . that the Bill of Rights was the child of the Enlightenment. Back of the guarantee of free speech lay faith in the power of an appeal to reason by all the peaceful means for gaining access to the mind."); see also J.S. Mir., On Liberty, in ON Liberty and Representattve Government 14-15 (R. McCallum ed. 1946) (1st ed. 1859) (free exchange of ideas encourages discovery of truth).

80. As Justice Harlan stated in Cohen v. California:

Freedom of expression is designed and intended to remove governmental restraints from the arena of public discussion, putting the decision as to what views shall be voiced largely into the hands of each of us, in the hope that use of such freedom will ultimately produce a more capable citizenry and more perfect polity ....

403 U.S. 15, 24 (1971).

81. As Justice Brandeis stated:

Those who won our independence . . . knew that order cannot be secured merely through fear of punishment for its infraction; that it is hazardous to discourage thought, hope and imagination; that fear breeds repression; that repression breeds hate; that hate menaces stable govern- 


\section{Copyright and Free Speech}

dissipate the force of ideological opposition to the political and socioeconomic status quo. ${ }^{82}$

Rather than contributing to a rational discussion, the visual arts may seek to elicit a visceral, emotional response. ${ }^{83}$ Artists who adopt radical aesthetic modes choose to undermine the assumption of systemic order and stability by depicting the chaos and disorder of modern society; ${ }^{84}$ their intent is to evoke cognitive shock and anxiety in the viewer in an effort to reveal the ideological inadequacy of the status quo ${ }^{85}$ Such emotive speech is not devoid of political content. ${ }^{88}$

\section{G. The Rationale for Extending First Amendment Protection}

Despite apparent conflict with the marketplace of ideas rationale of First Amendment theory, courts should still extend freedom of expression principles to appropriating speech. In assessing the dangers of permitting

ment; that the path of safety lies in the opportunity to discuss freely supposed grievances and proposed remedies ....

Whitney v. California, 274 U.S. 357, 375-76 (Brandeis, J., concurring) (emphasis added).

82. See id.; A. MEIkLejohn, supra note 69; Nimmer, The Right to Speak from Times to Time: First Amendinent Theory Applied to Libel and Misapplied to Privacy, 56 GaLIF. L. REv. 935, 949 (1968) ("Those who are not permitted to express themselves in words are more likely to seek expression in violent deeds.").

83. J. RuBlowsky, Pop ART 116 (1965) ("The pop artist is attempting to create art indistinguishable from the original subject matter and thereby evoke an emotional as well as a visual response.").

84. Kotz, supra note 6, at 60 (describing Rauschenberg's Quarter Mile Piece as containing "images rushing headlong into each other, reflecting the chaos, the irony and the natural beauty of the world").

Depictions of chaos also include artistic statements that criticize a particular ideology. See generally Gablik, ART UNDER tHe Dollar Sign, 69 ART-IN-AMERICA 13, 13 (1981) ("Modernism . . . saw itself as the negation rather than the complement of social practice, brandishing its mutinous intentions . . . against the spirit of worldly rationalism that is the social philosophy of bourgeois capitalism .....").

85. The Constitution has long protected the expression of views radically at odds with the status quo: "The First Amendment . . . rests on the assumption that the widest possible dissemination of information from diverse and antagonistic sources is essential to the welfare of the public . . .." Associated Press v. United States, 326 U.S. 1, 20 (1945). Unsettling speech is still protected speech:

[A] function of free speech under our system of government is to invite dispute. It may indeed best serve its high purpose when it induces a condition of unrest, creates dissatisfaction with conditions as they are, or even stirs people to anger. Speech is often provocative and challenging. It may strike at prejudices and preconceptions and have profound unsettling effects as it presses for acceptance of an idea.

Terminello v. Chicago, 337 U.S. 1, 4 (1949). See also Police Dept. v. Mosley, 408 U.S. 92,98 (1972). ("A]bove all else, the First Amendment means that government has no power to restrict expression because of its message, its ideas, its subject matter, or its content. ...").

86. Protected speech may strike at the emotions as well as at reason:

We cannot sanction the view that the Constitution, while solicitous of the cognitive content of individual speech has little or no regard for that emotive function which, practically speaking, may often be the more important element of the overall message sought to be communicated. Cohen v. California, 403 U.S. 15, 26 (1971).

The Supreme Court has never limited First Amendment protection to rational, as opposed to emotional, discussion. Rather, it has affirmed the "freedom to speak foolishly and without moderation." Baumgartner v. United States, 322 U.S. 665, 673-74 (1944). 
unrestricted expression, courts have always distinguished between emotive speech and speech that listeners may interpret as a call to action. ${ }^{87}$ Thus, highly emotive forms of oral and written speech-such as ideological slogans or ethnic slurs ${ }^{88}$-receive First Amendment protection so long as their expression does not cross the boundary between speech and action. ${ }^{89}$

The Supreme Court has held that the First Amendment protects the public's right to receive information and ideas. ${ }^{90}$ The Court has never suggested that information and ideas are exclusively or even primarily conveyed by written expression. Rather, the Gourt has acknowledged that free speech encompasses the guarantee of "suitable access to social, aesthetic, moral and other ideas and experiences." ${ }^{\text {"91 }}$ Furthermore, the Court has stated that the "right to hear extends to artistic as well as political expression."92 It is arbitrary and inconsistent to enforce First Amendment protection to irrational verbal appeals while denying such protection to visual discourse. ${ }^{23}$

87. Chaplinsky v. New Hampshire, 315 U.S. 568 (1942) (fighting words inherently likely to provoke violent reaction may be banned). In Cohen, the Court held that a protester's slogan on his jacket, "Fuck the draft," was protected speech: "At least so long as there is no showing of an intent to incite disobedience to or disruption of the draft, Cohen could not, consistently with the First and Fourteenth Amendments, be punished for asserting the evident position on the inutility or immorality of the draft his jacket reflected." 403 U.S. at 18. As Justice Frankfurter said in Dennis: "Throughout our decisions there has recurred a distinction between the statement of an idea which may prompt its hearers to take unlawful action, and advocacy that such action be taken." Dennis v. United States, 341 U.S. 494, 545 (1951) (Frankfurter, J., concurring); see also Emerson, supra note 69, at 917 (realization of First Amendment values rests upon distinction between "expression" and "action").

88. Brown v. Oklahoma, 408 U.S. 914 (1972) (Powell, J., concurring).

89. See, e.g., Organization for a Better Austin v. Keefe, 402 U.S. 415,419 (1971) ("[S]o long as the means are peaceful, the communication need not meet standards of acceptability."). The Cohen case provides another formulation:

To many, the immediate consequence of this freedom may often appear to be only verbal tumult, discord, and even offensive utterance. These are, however, within established limits, in truth necessary side effects of the broader enduring values which the process of open debate permits us to achieve. That the air may at times seem filled with verbal cacophony is, in this sense, not a sign of weakness but of strength.

403 U.S. at 24.

90. Kleindienst v. Mandel, 408 U.S. 755 (1972); Lamont v. Postmaster General, 381 U.S. 301, 307 (1965); cf. supra p. 1575 (discussing Time case).

91. Red Lion Broadcasting Co. v. FCC, 395 U.S. 367, 390 (1969).

92. Curtis Publishing Co. v. Butts, 388 U.S. 130, 147 (1967). Alexander Meiklejohn similarly found "novels and dramas and paintings and poems to fall within the category of public speech." Meiklejohn, The First Amendment Is an Absolute, 1961 Sup. CT. Rev. 243, 263.

93. A possible objection to unrestrained visual discourse is that demagogues may exploit visual symbols for political ends. A vigorous marketplace, however, can balance emotional appeals through rational debate. See Dennis v. United States, 341 U.S. 494, 503 (1951) (plurality opinion) ("speech can rebut speech, propaganda will answer propaganda, free debate of ideas will result in the wisest government policies"). Radical modes of speech may serve to initiate a productive dialogue. The form and manner of appropriated images in visual art convey an ideology which provides a contrast to the present norm, and thus provides a basis for political debate. Hadjinicolaou described this as "a specific combination of the formal and thematic elements of a picture through which people express the way they relate their lives to the conditions of their existence, a combination which constitutes a particular form of the overall ideology of a social class." HAdjInICOLAOU, ART History and Class Stuggle 95 (1973). 
Unconventional modes of speech both challenge and enrich the marketplace of ideas. A free society has an interest in promoting (or at least protecting) such radical, emotive speech, since the voicing of radical concepts leads to the adoption of moderate, beneficial reforms. ${ }^{94}$ Protection of radical ideas is, therefore, essential to societal progress.

Restrictive qualities of copyright are legitimately used to prohibit piracy-copying which contributes no original idea, but merely dilutes the economic worth of the original-but restriction is inappropriate when an infringer incorporates the visual image into a new artistic work that adds to society's cultural legacy.

\section{Protection of Appropriating Expression}

Interests in free expression do not require a legitimation of all appropriations of property; courts may weigh property interests against the value of creating broad contours of permissible speech. ${ }^{95}$ Under such a balancing, it would appear that courts may legitimately protect the appropriation of reproduced, visual images used for expressive purposes. Such appropriation neither precludes the copyright owner's possession and use of the original ${ }^{98}$ nor competes economically with the original use. ${ }^{97}$ Therefore, the incorporation does not deprive the copyright owner of any expected economic gain. ${ }^{98}$ The foreseeable harm of this appropriation appears minimal, while the detrimental effect of prohibiting expression which is dependent upon the appropriation of visual images is potentially great.9 ${ }^{29}$ Furthermore, to the extent that the appropriator's selection of ma-

94. Chaffee asserts that the more vocal speakers often represent the views of their quieter comrades:

[T]he pertinacious orators and writers who get hauled up are merely extremist spokesmen for a mass of more thoughtful and more retiring men and women, who share in varying degrees the same critical attitude toward prevailing policies and institutions. When you put the hotheads in jail, these cooler people do not get arrested-they just keep quiet. And so we lose things they could tell us, which would be very advantageous for the future course of the nation.

Z. Chaffee, Free Speech in the United States 561 (1946).

95. See Time, Inc. v. Bernard Geis Assoc., 293 F. Supp 130 (S.D.N.Y. 1968) (weighing property interest in photographs of John Kennedy's assassination against public interest in full news report) (discussed supra p. 1575).

96. In contrast with appropriation of material goods, appropriation of visual images for artistic expression merely creates an alternative use for a copyrighted image. It does not interfere with the copyright holder's use and enjoyment of the copyrighted material.

97. This would be a major consideration in applying the First Amendment defense. Appropriation for the purpose of commentary generally does not result in a product which serves the same function as the original copyrighted material. See supra p. 1571.

98. For example, a company gains when its copyrighted advertisement leads to increased sales of its product. The fact that an image from the same advertisement subsequently appears in a collage will not directly affect the economic gain resulting from its original publication.

99. See Meiklejohn, The First Amendment is an Absolute, in FreEdom of Expression 65, 77 (K. Middleton \& R. Mersky eds. 1981) ("Literature and the arts must be protected by the First Amendment. They lead the way toward sensitive and informed appreciation and response to the values out of which the riches of the general welfare are created."); see also Goldstein, Copyright and the 
terial is an arbitrary choice, compensation for such use would be a windfall to the individual copyright owner. ${ }^{100}$

The ability to substitute an infringing work for the copyrighted original should be of primary consideration when the defendant invokes a First Amendment defense. ${ }^{101}$ If a consumer may satisfy his desire to own the original material by purchasing the infringing work, a court may be justified in upholding the copyright holder's property interests. When the purpose of disclosure is to criticize or comment upon visual representations rather than to copy them for competing economic gain, it is unlikely that the physical qualities of the infringing work would ever substitute for the original.

It will be necessary then to examine the nature and purpose ${ }^{102}$ of the infringer's expression. Courts should extend First Amendment protection to visual works which use appropriated images to convey original expression, as this is consistent with First Amendment guarantees of free artistic expression. ${ }^{103}$ If the art work has significantly altered or transformed the copyrighted material so that the work as a whole adds meaning beyond that conveyed by the context of the copyrighted image alone, First Amendment protection is warranted.

Although the physical alteration involved in adapting a copyrighted image may be minimal, the conceptual nature of the transformation may itself be significant. For example, Marcel Duchamp, founder of the Dada movement, took a reproduction of the Mona Lisa, drew a mustache on the print, entitled it "L.H.O.O.Q.," and exhibited the work as an independent artistic creation. ${ }^{104}$ If the Mona Lisa were copyrighted and da Vinci sued for infringement, Duchamp's First Amendment defense should clearly prevail. Although he added but two black lines to an art print, Duchamp clearly conveyed original, conceptual expression through his work. L.H.O.O.Q., a critical condemnation of the traditional precepts of Western art, added to a legacy of aesthetic interpretation. ${ }^{103}$ Furthermore,

First Amendment, 70 Colum. L. Rev. 983, 989 (1970) ("Wise and independent political choices are not the outgrowth of exposure to political ideas alone. Essential, too, is exposure to the varieties of cultural experience-philosophy, science, the written, visual, and musical arts-which conduce to individual growth and freedom."). The visual arts not only "conduce" to individual growth but may explicitly advocate political choice. See supra notes 67-68.

100. See Buchloh, supra note 5 , at 58 (discussing random quality in montage technique). Viewed at a more abstract level, of course, paying royalties would compensate the class of producers of the original material for the takings of the class of appropriators.

101. See $3 \mathrm{M}$. NIMMER, supra note 39 , § 13.05[A][4], at 13-65.

102. See $3 \mathrm{M}$. NnMmER, supra note 39, \& 13.05]A][2][3], at 13-62-65.

103. See supra note 99. Although not all appropriating works contain explicit political content, the act of appropriation itself conveys a political ideology. See supra pp. 1579-80. Courts should accord First Amendment protection to the expression conveyed by the work and not require a showing of suppression of political speech.

104. For an account of appropriation in Dadaist montage works, see Buchloh, supra note 5 at 46.

105. See H. Blocker, supra note 31 (contemporary art genre can only be understood as a com- 
despite the minimal alteration to the original work, it is unlikely that potential purchasers would consider L.H.O.O.Q. a desirable substitute for the Mona Lisa.

In contrast to existing fair use tests, a First Amendment defense to copyright infringement would protect expression in the visual arts. Infringers could assert traditional fair use rationales for the incorporation of copyrighted material. That is, a court may still examine the nature ${ }^{\mathbf{3 0}}$ of the copyrighted work to determine if it conveys original expression and the purpose $\mathrm{e}^{\mathbf{1 0 7}}$ of the work to see if it competes directly with the incorporated material. Artists who appropriate copyrighted images for the purpose of artistic expression will easily pass such scrutiny, while their First Amendment defense would eliminate the need for compliance with the extant, narrow fair use tests. ${ }^{108}$

-Patricia Krieg

ment on traditional concepts of art).

106. 17 U.S.C. § 107(2) (1982).

107. 17 U.S.C. $\S 107(1)(1982)$.

108. See supra TAN 34-52 (discussing inappropriateness of fair use inquiry). 
